ECREG STUDIES

Vol. 12, No. 3, 2019 www.ers.edu.pl PDF OPEN ACCESS eISSN 2451-182X

\section{sciendo}

Authors' contribution/

Wkład autorów:

A. Study design/ Zaplanowanie badań

B. Data collection/ Zebranie danych

C. Statistical analysis/ Analiza statystyczna

D. Data interpretation/ Interpretacja danych/

E. Manuscript preparation/ Przygotowanie tekstu

F. Literature search/ Opracowanie piśmiennictwa

G. Funds collection/ Pozyskanie funduszy

ORIGINAL ARTICLE

JEL code: I25, 020, Q01

Submitted:

August 2019

Accepted:

August 2019

Tables: 2

Figures: 0

References: 24

\section{ECONOMIC AND REGIONAL STUDIES}

STUDIA EKONOMICZNE I REGIONALNE

ISSN 2083-3725

Volume 12, No. 3, 2019

\title{
THE PLACE OF STATE HIGHER VOCATIONAL SCHOOLS (SHVS) FROM THE LUBLIN VOIVODESHIP IN LOCAL AND REGIONAL DEVELOPMENT STRATEGIES
}

\author{
MIEJSCE PWSZ Z WOJEWÓDZTWA LUBELSKIEGO W STRATEGIACH \\ ROZWOJU LOKALNEGO I REGIONALNEGO
}

\author{
Mariusz Pyra ${ }^{1(\mathrm{~A}, \mathrm{~B}, \mathrm{C}, \mathrm{D}, \mathrm{E}, \mathrm{F}, \mathrm{G})}$
}

${ }^{1}$ Pope John Paul II State School of Higher Education in Biała Podlaska

Państwowa Szkoła Wyższa im. Papieża Jana Pawła II w Białej Podlaskiej

Pyra, M. (2019). The place of State Higher Vocational Schools (SHVS) from the Lublin Voivodeship in local and regional development strategies/ Miejsce PWSZ z województwa lubelskiego w strategiach rozwoju lokalnego i regionalnego. Economic and Regional Studies, 12(3), 302-311.

https://doi.org/10.2478/ers-2019-0027

\section{Summary}

Subject and purpose of work: The objective of this elaboration is to specify the place of state higher vocational schools from the Lublin voivodeship in development strategies of various territorial levels.

Materials and methods: The method of document research was applied within this elaboration, which consists of analysing the content of strategies and development plans. Within the study the induction method was also used (stage of literary studies), analysis and synthesis (stage of empirical research), deduction method (conceptual stage).

Results: References to state vocational schools occur more frequently in diagnostic segments than the programming ones of these strategic documents. Territorial self-government units (TSU) of the Chełmski subregion consider to a larger degree and thus, appreciate the functioning and public functions of vocational schools than it is the case with the Bialski or Zamojski subregions.

Conclusions: Within the regional strategic documents of the Lublin Voivodeship, statements referring to higher education refer rather to general matters. Within the local strategic documents, one may more frequently encounter more direct and literal references to the methods of possibilities of cooperation and co-action between TSU and business with state vocational schools for the benefit of local territorial arrangements.

Keywords: SHVS, development, strategy, local and regional scale

ORYGINALNY ARTYKUŁ NAUKOWY

Klasyfikacja JEL: I25, 020, Q01

Zgłoszony:

sierpień 2019

Zaakceptowany:

sierpień 2019

Tabele: 2

Rysunki: 0

Literatura: 24

\section{Streszczenie}

Przedmiot i cel pracy: Celem opracowania jest określenie miejsca państwowych wyższych szkół zawodowych z województwa lubelskiego w strategiach rozwojowych różnych szczebli terytorialnych.

Materiały i metody: Do opracowania materiału zastosowano metodę badania dokumentów polegającą na analizie treści strategii i planów rozwojowych. W pracy wykorzystano również metodę indukcji (etap studiów literaturowych), analizę i syntezę (etap badań empirycznych), metodę dedukcji (etap koncepcyjny).

Wyniki: Odniesienia do publicznych uczelni zawodowych częściej pojawiają się w członach diagnostycznych aniżeli programowych tych dokumentów strategicznych. Jednostki samorządu terytorialnego subregionu chełmskiego w znacznie większym stopniu uwzględniają, a co za tym idzie doceniają funkcjonowanie i działalność publicznej uczelni zawodowej niż ma to miejsce w przypadku subregionu bialskiego czy zamojskiego.

Wnioski: W regionalnych dokumentach strategicznych województwa lubelskiego sformułowania dotyczące szkolnictwa wyższego odnoszą się raczej do spraw ogólnych. W lokalnych dokumentach strategicznych częściej można zauważyć bardziej bezpośrednie i literalne odniesienia dotyczące sposobów możliwości współpracy i współdziałania JST i biznesu z publicznymi uczelniami zawodowymi dla dobra terytorialnych układów lokalnych.

Słowa kluczowe: PWSZ, rozwój, strategia, skala lokalna i regionalna

Address for correspondence/ Adres korespondencyjny: dr Mariusz Pyra (ORCID 0000-0001-8246-851X), Państwowa Szkoła Wyższa im. Papieża Jana Pawła II w Białej Podlaskiej, Wydział Nauk Ekonomicznych i Technicznych, ul. Sidorska 95/97, 21-500 Biała Podlaska, Polska; tel.: + 48 83 344 99 00 w. 254, e-mail:m.pyra@dydaktyka.pswbp.pl

Journal indexed in/ Czasopismo indeksowane w: AGRO; AgEcon Search; Baidu Scholar; BazEkon; CEON; CNKI Scholar; CNPIEC - cnpLINKer; EBSCO; Google Scholar; Index Copernicus ICV 2018: 100,00; J-Gate; KESLI-NDSL; Naviga (Softweco); POL-index; Polish Ministry of Science and Higher Education, 2015-2018: 9 points; Primo Central (ExLibris); QOAM; ReadCube; Summon (Serials Solutions/ProQuest); TDNet; WanFang Data; WorldCat (OCLC). Copyright: (C) 2019 Pope John Paul II State School of Higher Education in Biała Podlaska, Mariusz Pyra. All articles are distributed under the terms of the Creative Commons Attribution-NonCommercial-ShareAlike 4.0 International (CC BY-NC-SA 4.0) License (http://creativecommons.org/licenses/by-nc-sa/4.0/), allowing third parties to copy and redistribute the material in any medium or format and to remix, transform, and build upon the material, provided the original work is properly cited and states its license. 


\section{Introduction}

Development of education at the higher level is generally considered as the basic and necessary growth factor. Expanding education in higher educational schools is determined by a number of factors of social, economic, political and cultural nature. Social-systemic transformation in Poland constituted a critical breakthrough in the scope of making education accessible at the higher level, turning third-degree education into one of the most dynamically growing areas of social life. Within twenty-seven years, substantial shifts of quantitative and institutional nature occurred within it (Borys, 2010). As time passed, the importance of individual factors within the process of social-economic development underwent substantial changes. Due to the scientific and technological progress as well as the changing requirements of modern economy, some types of factors lost their significance, but also certain unique benefits of other types started to be noticed. After implementing basic economic reforms restoring economic freedom and free market mechanisms based on private ownership system the so-called soft, modern development factors identified with knowledge-based economy using non-material forms of capital - intellectual, human or social capital started to be searched for (Adamowicz, 2014). A significant role in this scope, apart from higher education schools, was played by state higher vocational schools which started to be launched at the end of the XXth century in order to increase enrolment factors at a higher level the low level of which hindered the process of local development. Creation of a new type of higher education schools was supported, apart from the Bologna process and the Ministry of Science and Higher Education, by territorial self-government units which considered them as a chance for the region stemming from the sole existence of such educational facilities. It seems justifiable thus to analyse how the issue of relations between SHVS and TSU presents itself after 20 years of existence of these schools, especially in terms of their place in local and regional development strategies, within the area of the Lublin Voivodeship. Such objective was selected by the author of this elaboration.

\section{Historical overview of higher vocational education in Poland}

The idea of creating higher vocational schools originated from the period of partitions, but historical events caused difficulties in its materialization, especially in the context of world wars. Only in 1947, pursuant to a decree on organizing science and higher education, vocational schools could be launched without any obstacles and their key task was to educate candidates for employees with the highest practical preparation for a given profession. However, pursuant to the Act from 1951 on higher education and scientific employees the division into academic and vocational schools was abandoned, raising the latter

\section{Wstęp}

Rozwój edukacji na poziomie wyższym jest powszechnie uznawany jako podstawowy i niezbędny czynnik rozwoju. Rozszerzenie kształcenia na uczelniach wyższych uwarunkowane jest przez szereg czynników natury społecznej, gospodarczej, politycznej i kulturowej. Transformacja społeczno-ustrojowa w Polsce stanowiła wielki przełom w zakresie udostępnienia kształcenia na poziomie wyższym, czyniąc szkolnictwo wyższe jednym z najbardziej dynamicznie rozwijających się obszarów życia społecznego. W ciągu dwudziestu siedmiu lat nastąpiły w nim znaczne przemiany o charakterze ilościowym oraz instytucjonalnym (Borys, 2010). Wraz z upływem czasu znaczenie poszczególnych czynników w procesie rozwoju społeczno-ekonomicznego ulegało bardzo istotnym zmianom. Z uwagi na postęp naukowy oraz technologiczny, a także zmieniające się wymagania nowoczesnej gospodarki, niektóre rodzaje czynników traciły na znaczeniu, ale też zaczęto dostrzegać niezwykłe korzyści w innych rodzajach. Po wdrożeniu podstawowych reform ekonomicznych przywracających wolność ekonomiczną i mechanizmy rynkowe, opartych na prywatnym systemie własności, zaczęto poszukiwać tzw. miękkich, nowoczesnych czynników rozwoju, utożsamianych z gospodarką opartą na wiedzy, wykorzystującą niematerialne formy kapitału - kapitał intelektualny, ludzki, społeczny (Adamowicz, 2014). Istotną rolę w tym zakresie, obok uczelni akademickich, zaczęły odgrywać publiczne uczelnie zawodowe, które powstawały pod koniec XX w. w celu wzrostu współczynnika skolaryzacji na poziomie wyższym, którego niski poziom hamował proces rozwoju lokalnego. Na wykreowanie nowego typu szkół wyższych, oprócz procesu bolońskiego i MNiSW, miały jednostki samorządu terytorialnego, które upatrywały szanse dla regionu $\mathrm{z}$ faktu samego istnienia takiej placówki edukacyjnej. Zasadne wydaje się więc przeanalizowanie, jak kwestia relacji PWSZ - JST przedstawia się po 20 latach istnienia tych szkół, zwłaszcza pod kątem ich umiejscowienia w strategiach rozwoju lokalnego i regionalnego, ograniczając się do regionu lubelskiego. Taki też cel postawił sobie autor tego opracowania.

\section{Rys historyczny wyższego szkolnictwa zawodo- wego w Polsce}

Idea utworzenia wyższych szkół zawodowych zrodziła się w okresie rozbiorów, ale wydarzenia historyczne powodowały trudności w jej zmaterializowaniu się, zwłaszcza w kontekście wojen światowych. Dopiero w 1947 roku na mocy dekretu o organizacji nauki i szkolnictwa wyższego, uczelnie zawodowe mogły być tworzone bez żadnych przeszkód, a ich głównym zadaniem było kształcenie kandydatów na pracowników o najwyższym dla danego zawodu przygotowaniu praktycznym. Jednak na mocy ustawy z 1951 roku o szkolnictwie wyższym i pracownikach nauki zniknęło rozróżnienie na szkoły akademickie 
one to the rank of academic schools. The appearing discussions in academic environments regarding reasonableness of this type of changes led in 1958 to reinstating the division of schools. Pursuant to the regulations of the Act higher engineering schools were created most of all as well as higher teaching schools. Amendments to the Act from 1965 slightly reduced the distance between two sectors in the higher educational system, assigning the scientificresearch tasks also to higher vocational schools. Turbulent fates of vocational schools are visible through yet another amendment of the Act on higher education from 1968, as a result of which they lost their status and were carried out solely as uniform MA studies (Zimny, 2017). Substantial changes in this regard were introduced by the Act from 26 June 1997 on higher vocational schools (Journal of Laws from 1997, No. 96, item 590).

To sum up one must note that the sector of higher education in Poland was and is still subjected to constant reorganization (Act 2.0). Changes in the organization and structure of higher education often tend to be justified, since within a dynamic reality the function of science, education and upbringing shifts which triggers the search for new, more and more optimal organizational-legal solutions. This often takes place as an experiment, before this process is confirmed or quite the opposite (Jaroszyński, 1971). But one may also get the impression, having analysed subsequent legal regulations with regards to the sector of higher vocational education, the treatment of higher vocational schools by state authorities and the legislator is rather instrumental and that there are no long-term plans as to their functioning in place (Kowalska, 2013).

At present, the place of state higher vocational schools within the system of higher education is to be strengthened in accordance with the law on higher education and science (Journal of Laws from 2018, item 1668). Additional support appeared (apart from subsidy) for regional universities (contest "Regional Perfection Initiatives) for public vocational schools (contest "Didactic Perfection Initiatives"). The basic task of a vocational schools is to conduct practical as well as specialized education, but also to build relations with the environment (so called third mission), including cooperation with business and TSU in order to support social-economic process, especially at the local and regional level.

\section{Essence of local and regional development}

The concept of local development entered economic practice in the 80's of the 20th century. However, only launching in 1990 the communal selfgovernment and, subsequently 9 years later the poviat and voivodeship self-government (new division) caused the concept to reach practical meaning. The overriding goal of creating communities is to form conditions for their development which signifies increasing the possibilities of fulfilling the needs of all community participants (Zasadzki, 2005). i zawodowe, podnosząc te drugie do rangi uczelni akademickich. Pojawiające się dyskusje w środowisku akademickim o zasadności tego typu zmian, doprowadziły w 1958 roku do przywrócenia podziału szkół. Na mocy przepisów ustawy tworzone były przede wszystkim wyższe szkoły inżynierskie oraz wyższe szkoły nauczycielskie. Nowelizacja ustawy z 1965 roku nieznacznie zredukowała dystans między dwoma sektorami w szkolnictwie wyższym, przypisując zadania naukowo - badawcze również wyższym szkołom zawodowym. Burzliwe losy uczelni zawodowych obrazuje kolejna nowelizacja ustawy o szkolnictwie wyższym z 1968 roku, w wyniku której utraciły one swój status i prowadzone były wyłącznie jednolite studia magisterskie (Zimny, 2017). Znaczące zmiany $\mathrm{w}$ tej materii wprowadziła dopiero ustawa $\mathrm{z}$ dnia 26 czerwca 1997 roku o wyższych szkołach zawodowych (Dz.U. z 1997 r., Nr 96, poz. 590).

Reasumując należy stwierdzić, że sektor szkolnictwa wyższego w Polsce podlegał i nadal podlega (Ustawa 2.0.) ciągłym przeobrażeniom. Zmiany $\mathrm{w}$ organizacji i strukturze szkolnictwa wyższego bywają często uzasadnione, bowiem w dynamicznej rzeczywistości zmienia się funkcja nauki, oświaty i wychowania, co skłania do poszukiwania nowych, coraz bardziej optymalnych rozwiązań organizacyjno-prawnych. Odbywa się to nierzadko na zasadzie eksperymentu, zanim się ten proces nie potwierdzi lub wręcz przeciwnie (Jaroszyński, 1971). Ale można też odnieść wrażenie, analizując kolejne przepisy prawne w odniesieniu do sektora wyższego szkolnictwa zawodowego, o instrumentalnym traktowaniu wyższych szkół zawodowych przez władze rządowe i ustawodawcę, a także braku długofalowego planu ich funkcjonowania (Kowalska, 2013).

Obecnie miejsce państwowych wyższych szkół zawodowych w systemie edukacji wyższej ma być wzmocnione, zgodnie z prawem o szkolnictwie wyższym i nauce (Dz.U. z 2018, poz. 1668). Pojawiło się dodatkowe wsparcie (oprócz subwencji) dla uczelni regionalnych (konkurs „Regionalne Inicjatywy Doskonałości), dla publicznych uczelni zawodowych (konkurs „Dydaktyczne Inicjatywy Doskonałości”). Podstawowym zadaniem uczelni zawodowej jest prowadzenie kształcenia, w tym specjalistycznego, praktycznego, ale też odpowiednie relacje z otoczeniem (tzw. trzecia misja), w tym współpraca z biznesem i JST w celu wsparcia procesu rozwoju społeczno-gospodarczego, zwłaszcza na szczeblu lokalnym i regionalnym.

\section{Istota rozwoju lokalnego i regionalnego}

Pojęcie koncepcji rozwoju lokalnego weszło do praktyki gospodarczej w latach 80-tych XX wieku. Jednakże dopiero powołanie do życia w 1990 roku samorządu gminnego, a następnie 9 lat później samorządu powiatowego i wojewódzkiego (nowy podział) spowodowało, że pojęcie to nabrało praktycznego znaczenia. Nadrzędnym celem utworzonych wspólnot jest bowiem kreowanie warunków do ich rozwoju, co oznacza zwiększenie możliwości zaspakajania potrzeb wszystkich uczestników wspólnoty (Zasadzki, 2005). 
Local development constitutes a special type of process which concerns significant changes occurring in the microregion, that is the local social-territorial setup within the region. This setup, earmarked from the environment, is characterized normally by special spatial, economic and cultural features with a different hierarchy of needs and values. Detecting the local scale of the scope of social, economic and spatial development becomes particularly complicated, since communes and poviats function and develop as an integral part of the region, using the goods and services originating from other areas, whilst at the same time producing and delivering their products towards the broadly understood environment. This multidirectional interactions make simultaneous defining the concept of development at a local scale difficult (Szewczuk, Kogut-Jaworska, Zioło, 2011).

The effect of local development is the process at microregion level of creating new values in the form of new companies, workplaces and new goods and services fulfilling the local and supralocal demand. Hard location factors are significant here in the form of real estate and infrastructural devices, as well as soft factors, intangible, such as knowledge, qualifications and new skills of the local society (Klasik, 1996).

Development at the level of each self-government voivodeship is considered already in the categories of regional development. As a result of this distinction both in scientific research and in self-governmental practice, ventures concerning development are considered at the regional and local level (microregional). Strict cause-and-effect relationships occur amongst these processes. Separate consideration of significance of local and regional development categories is neither justifiable nor possible. It stems from the lack of objective categories of valuing the processes occurring on these layers as well as diversifying their main characteristics and strengths of their impacts on the environment. Therefore, the subject of studies and analyses often becomes the issue of local and regional development since the scopes of their interests permeate one another to a large degree.

Local and regional development is animated by three basic mutually related to one another groups of economic-social phenomena creating the mechanism of local and regional development. These are:

- manner of functioning of local and regional markets;

- Impact of external conditions (national and foreign) systemic solutions and macro-economic policy;

- Impact of local and regional authorities on economic-social situation of micro or mezzo region (Adamowicz, 2003).

Making reference at this point to the context of assigning to public vocational schools the role of creator of developmental processes, it seems necessary to review the content of strategic documents for the Lublin Voivodeship in terms of the fact of existence of such educational institution.
Rozwój lokalny stanowi szczególny proces, który dotyczy ważnych zmian zachodzących w mikroregionie, tj. lokalnym układzie społeczno-terytorialnym $\mathrm{w}$ obrębie regionu. Ten wyodrębniony $\mathrm{z}$ otoczenia układ charakteryzuje się zazwyczaj specjalnymi cechami przestrzeni, gospodarki, kultury oraz odmienną hierarchią potrzeb i wartości. Rozpoznanie w skali lokalnej zasięgu rozwoju społecznego, gospodarczego i przestrzennego staje się szczególnie skomplikowane, ponieważ gmina czy powiat funkcjonuje i rozwija się jako integralna część regionu, korzystając z dóbr i usług pochodzących z innych terenów, jednocześnie produkując i dostarczając swoje produkty na rzecz szeroko rozumianego otoczenia. Te wielokierunkowe interakcje powodują, że jednoznaczne zdefiniowanie pojęcia rozwoju w skali lokalnej jest trudne (Szewczuk, Kogut-Jaworska, Zioło, 2011).

Efektem rozwoju lokalnego jest proces tworzenia na szczeblu mikroregionu nowych wartości w postaci nowych firm, miejsc pracy oraz nowych dóbr i usług zaspokajających popyt lokalny i ponadlokalny. Istotne sa tutaj twarde czynniki lokalizacyjne w formie nieruchomości i urządzeń infrastrukturalnych, jak również czynniki miękkie, niematerialne, takie jak wiedza, kwalifikacje i nowe umiejętności społeczności lokalnej (Klasik, 1996).

Rozwój na poziomie każdego województwa samorządowego rozpatrywany jest już w kategoriach rozwoju regionalnego. W wyniku tego rozróżnienia, zarówno w badaniach naukowych, jak i w praktyce samorządowej, przedsięwzięcia dotyczące rozwoju rozpatruje się na poziomie regionalnym i lokalnym (mikroregionalnym). Między tymi procesami występują ścisłe zależności przyczynowo - skutkowe. Rozdzielne rozpatrywanie ważności kategorii rozwoju lokalnego i regionalnego nie jest ani zasadne, ani możliwe. Wynika to z braku obiektywnych kryteriów wartościowania procesów zachodzących na tych płaszczyznach, a także zróżnicowanie ich głównych charakterystyk i siły oddziaływania na otoczenie. Dlatego przedmiotem studiów i analiz staje się często problematyka rozwoju lokalnego i regionalnego, gdyż zakresy ich zainteresowań $\mathrm{w}$ dużym stopniu przenikają się wzajemnie.

Rozwój lokalny i regionalny jest animowany przez trzy podstawowe, wzajemnie ze sobą powiązane grupy zjawisk ekonomiczno-społecznych tworzących mechanizm rozwoju lokalnego i regionalnego. Sa to:

- sposób funkcjonowania rynków lokalnych i regionalnych;

- wpływ uwarunkowań zewnętrznych (krajowych i zagranicznych) rozwiązań ustrojowych i polityki makroekonomicznej;

- oddziaływanie władz lokalnych i regionalnych na sytuację ekonomiczno-społeczną mikro czy mezoregionu (Adamowicz, 2003).

Przywołując w tym miejscu kontekst przypisania publicznym uczelniom zawodowym roli kreatora procesów rozwojowych, niezbędny wydaje się być przegląd treści dokumentów strategicznych z woj. lubelskiego pod kątem faktu istnienia takiej instytucji edukacyjnej. 


\section{Research results}

The most important feature in planning a strategic area, that is a region, voivodeship, poviat, commune is to optimise the processes of its functioning and developing. The crucial function of strategic development plan elaboration for a given area is to maximise the efficiency as well as effectiveness of managing the subject of strategy as its entity in order to support the development of its economic, social and environmental layers. The task of self government authorities as an entity is, among others, to prepare the goals, actions as well as to ensure their completion in agreement with the stakeholders, that is residents, entrepreneurs and institutions, including higher schools (Wiatrak, 2016).

Efficiency of development strategies as a management tool depends, among others, on the premises which triggered their elaboration while its assessment ought to be carried out through such factors like: degree of acceptance of strategic arrangements by inhabitants, likelihood of continuity of realization of strategic arrangements by authorities, quality of document in the aspect of, among others, considering the most critical local and regional actors, such as undoubtedly state higher vocational schools (Guzal-Dec, 2015).

Due to the main object of interest of the carried out deliberations, the researched group is formed by three entities, thus all state higher vocational schools in the Lublin region: Pope John Paul II State School of Higher Education in Biała Podlaska (PSW BP), the State School of Higher Education in Chełm (PWSZ) and the State School of Higher Education (PWSZ) in Zamość. Each of the selected PWSZ has its own unique nature, stemming among others from the visible strive towards specialisations.

The analysis of Development Strategy for the Lublin Voivodeship for the years 2006-2013 (with perspective up to 2020) indicates a significant role of the sector of education at the higher level. One of the more significant chances for the local development within the Lublin region is educating the staff on appropriate level and in professions which will be useful on the local market. These actions ought to be assigned to higher schools at the regional level.

Development Strategy of the Lublin Voivodeship for the years $2014-2020$ (with perspective up to 2030) focuses above all on the capital of the region as an academic centre, thus on the universities and research institutes located there. It only mentions that „in many smaller towns of the region higher schools operate but they are of importance mainly as educational institutions while their research potential is rather small, especially in technical and science fields. Within the region one may find higher schools with unique profiles of teaching, such as for instance pilot trainings - including helicopter pilots at PWSZ in Chełm" (SRWL, 2014).

Regional Innovation Strategy of the Lublin Voivodeship until 2020 was elaborated by a team of experts appointed by the Marshal Office of the Lublin Voivodeship with support of the Department

\section{Wyniki badań}

Najważniejszą cechą planowania strategicznego obszaru, tj. regionu, województwa, powiatu i gminy jest optymalizacja procesów jego funkcjonowania i rozwoju. Kardynalną funkcję planowania strategicznego planu rozwoju danego obszaru stanowi maksymalizacja skuteczności, a także efektywności zarządzania przedmiotem strategii przez jego podmiot, aby sprzyjać rozwojowi gospodarczej, społecznej i środowiskowej płaszczyzny tego przedmiotu. Zadaniem władz samorządowych jako podmiotu jest m.in. przygotowanie celów, działań, a także zapewnienie ich wykonania w porozumieniu z interesariuszami, czyli mieszkańcami, przedsiębiorcami i instytucjami, w tym szkołami wyższymi (Wiatrak, 2016).

Skuteczność strategii rozwojowych jako narzędzia zarządzania uzależniona jest m.in. od tego, jakie przesłanki powodowały ich opracowanie, a jej ocena powinna być dokonywana poprzez takie czynniki, jak: stopień akceptowalności ustaleń strategicznych przez mieszkańców, prawdopodobieństwo ciągłości realizacji ustaleń strategicznych przez władze, jakość dokumentu w aspekcie m.in. uwzględnienia najważniejszych aktorów lokalnych i regionalnych, do których niewątpliwie należą państwowe wyższe szkoły zawodowe (Guzal-Dec, 2015).

Ze względu na główny przedmiot zainteresowania prowadzonych rozważań, grupę badaną tworzą trzy podmioty, czyli wszystkie publiczne uczelnie zawodowe z regionu lubelskiego: Państwowa Szkoła Wyższa im. Papieża Jana Pawła II w Białej Podlaskiej (PSW BP), Państwowa Wyższa Szkoła Zawodowa w Chełmie (PWSZ) oraz Państwowa Wyższa Szkoła Zawodowa (PWSZ) im. Szymona Szymonowica w Zamościu. Każda z wybranych PWSZ posiada swój unikalny charakter wynikający między innymi z widocznego dążenia do specjalizacji.

Analiza Strategii Rozwoju Województwa Lubelskiego na lata 2006-2013 (z perspektywą do 2020 roku) wskazuje na znaczącą rolę sektora kształcenia na poziomie wyższym. Jedną z istotniejszych szans dla rozwoju lokalnego $\mathrm{w}$ regionie lubelskim jest kształcenie kadr na odpowiednim poziomie i w zawodach, które będą przydatne na rynku lokalnym. Działania te należy przypisać uczelniom wyższym na poziomie regionalnym.

Strategia Rozwoju Województwa Lubelskiego na lata 2014 - 2020 (z perspektywą do 2030 roku) koncentruje się przede wszystkim na stolicy regionu jako ośrodku akademickim, a tym samym na zlokalizowanych w nim uczelniach i instytutach badawczych. Znajduje się w niej tylko wzmianka, iż „w wielu mniejszych miastach regionu działają szkoły wyższe, ale mają one znaczenie głównie jako instytucje edukacyjne, ich potencjał badawczy jest bardzo mały, zwłaszcza w dziedzinach technicznych i ścisłych. W regionie znajdują się szkoły wyższe o unikatowym profilu kształcenia, jak np. szkolenie pilotów - w tym helikopterów - w PWSZ w Chełmie" (SRWL, 2014).

Regionalna Strategia Innowacji Województwa Lubelskiego do roku 2020 została opracowana przez zespół ekspertów powołany przez Urząd Marszał- 
of Economy and Innovation. This strategy is a programme document that specifies the most important planes for region's development (in the context of innovation). It is based on endogenous potential of spatial increase in his case as types of activity which already indicate a certain degree of specialization or have the potential in this regard. As a consequence, the strategy has been based on the so-called intelligent specializations. Intelligent specialization was elaborated on the basis of an in-depth analysis of resources and the state of development and potential: economic, raw materials, technological and scientific of the region. The document of the Strategy for LV indicates four areas of smart specialization: bioeconomy, medicine and health, IT and automation, low-emission energy sector (RSI WL, 2014). kowski Województwa Lubelskiego przy wsparciu Departamentu Gospodarki i Innowacji. Strategia ta jest dokumentem programowym określającym najważniejsze płaszczyzny dla rozwoju regionu (w kontekście innowacyjności). Opiera się na endogenicznym potencjale wzrostu postrzeganego w tym wypadku jako rodzaje działalności, które już wykazują pewien stopień specjalizacji lub posiadają potencjał w tym obszarze. W konsekwencji strategia oparta została na tzw. inteligentnej specjalizacji. Inteligentna specjalizacja została opracowana na podstawie dogłębnej analizy zasobów oraz stanu rozwoju i potencjału: gospodarczego, surowcowego, technologicznego oraz naukowego regionu. W RSI WL wskazano cztery obszary inteligentnej specjalizacji: biogospodarkę, medycynę i zdrowie, informatykę i automatykę, energetykę niskoemisyjną (RSI WL, 2014).

Table 1. Didactic-scientific activity versus smart specializations in the Lublin Voivodeship

Tabela 1. Działalność dydaktyczno-naukowa a inteligentne specjalizacje woj. lubelskiego

\begin{tabular}{|l|c|c|c|}
\hline \multicolumn{1}{|c|}{ Specification/ Wyszczególnienie } & PSW BP & PWSZ Chełm & PWSZ Zamość \\
\hline Bioeconomy/ Biogospodarka & + & + & \\
\hline Medicine and health/ Medycyna i zdrowie & + & + & + \\
\hline IT and automation/ Informatyka i automatyka & + & + & \\
\hline Low-emission energy sector/ Energetyka niskoemisyjna & + & & + \\
\hline
\end{tabular}

Source: Own elaboration.

Źródło: Opracowanie własne.

When analysing the functioning of sate vocational schools from the Lubelskie region one ought to point out that all 4 smart specializations may be found within the didactic-research scope of interest of PSW BP, which is reflected, among others, by its infrastructural setup (specialist laboratories), staff resources, organizational structure as well as the realized directions of studies and their specializations. The activities of the remaining two universities, that is of PWSZ in Chełm and PWSZ in Zamość, to a slightly smaller degree corresponds to the areas of smart specializations. Despite good adjustment of public profiles of vocational schools here are no specific references made to these schools as an endogenous developmental potential of the Lublin region in RIS LV. A very general statement in this regard appears, stating that the purpose of smart specialization is possibly best adjustment of fields of development to their specific social-economic conditions, thus adjustment under the triangle: science - education- economy(http://rsi.lubelskie. $\mathrm{pl} /$ index.php/regionalna-strategia-innowacji, access 04.08.2019).

Development Strategy of Bialski Poviat for the years 2007-2015 covers with its scope solely the diagnostic aspect of higher education, distinguishing individual higher schools that function within the area of the poviat, including Pope John Paul II PSW in Biała Podlaska. Whilst, there is no programme aspect of the strategy with regards to higher education (Development Strategy for Bialski Poviat for the years 2007-2015, 2018).

Within the Development Strategy for Chełmski Poviat for the years 2008-2015 it was highlighted
Analizując funkcjonowanie publicznych uczelni zawodowych z regionu lubelskiego należy stwierdzić, iż wszystkie 4 inteligentne specjalizacje są w zainteresowaniu dydaktyczno - badawczym PSW BP, co przejawia się m.in. zapleczem infrastrukturalnym (specjalistyczne laboratoria), zasobami kadrowymi, strukturą organizacyjną, jak również realizowanymi kierunkami studiów oraz ich specjalnościami. Działalność pozostałych uczelni tj. PWSZ w Chełmie oraz PWSZ w Zamościu, w nieco mniejszym stopniu odzwierciedla obszary inteligentnych specjalizacji. Pomimo dobrego dopasowania profili publicznych uczelni zawodowych, brak jest konkretnych odniesień do tych szkół jako endogenicznego potencjału rozwojowego regionu lubelskiego w RSI WL. Pojawia się jedynie w tym zakresie bardzo ogólnikowe stwierdzenie, że celem inteligentnej specjalizacji jest możliwie najlepsze dopasowanie kierunków rozwoju do ich specyficznych uwarunkowań społeczno-gospodarczych, czyli dopasowanie w ramach trójkąta: nauka - edukacja - gospodarka (http://rsi.lubelskie.pl/index.php/regionalna-strategia-innowacji, dostęp 04.08.2019).

Strategia Rozwoju Powiatu Bialskiego na lata 2007-2015 obejmuje swoim zakresem jedynie aspekt diagnostyczny dotyczący szkolnictwa wyższego, wyróżniając poszczególne szkoły wyższe funkcjonujące na terenie powiatu, w tym PSW im. Papieża Jana Pawła II w Białej Podlaskiej. Natomiast brakuje tutaj aspektu programowego strategii odnośnie szkolnictwa wyższego (Strategia Rozwoju Powiatu Bialskiego na lata 2007-2015, 2008).

W Strategii Rozwoju Powiatu Chełmskiego na lata 2008-2015 uwypuklono, iż szczególną rolę w rozwoju powiatu pełni PWSZ w Chełmie. Wsparcie wy- 
that special role in the poviat development is performed by PWSZ in Chełm. Support for the efforts of school authorities, striving to create a training airport in the town of Depułtycze Królewskie, as well as development of transnational cooperation of the school was considered as a significant element of poviat's development, and thus the accent was placed on diagnostic and programme strategy with regards to public vocational school. However, within the subsequent version of the strategy (after an update) with the perspective for 2020 there were no provisions in this scope (Strategy for the Development of Chełmski Poviat for the years 2008-2015, 2008).

The Development Strategy of Zamojski Poviat for the years 2007-2020 covers with its scope solely the diagnostic aspect concerning higher education, distinguishing individual higher education schools that operate within the area of the poviat, including Higher Education (PWSZ) in Zamość. Whilst, there is no programme aspect within the strategy regarding higher education (Development Strategy of Zamojski Poviat for the years 2007-2020, 2007).

Within the Integrated Development Strategy of the Municipal Functional Area Biała Podlaska for the years 2015-2020 (with perspective up to 2030) it was stated that the area has modern scientificresearch resources at its disposal, which function in PSW in Biała Podlaska. These recourses include Centre for Researches on Innovation and the Regional Environment, Agriculture and Innovative Technologies Research Centre EKO-AGRO-TECH and create the possibility of cooperation with medical, power, road, rail, air, construction, tourist, food and trade industries, and thus impacting the development of Urban Functional Area (Integrated Development Strategy of Municipal Functional Area in Biała Podlaska for the years 2015-2020, 2015).

Within the Development Strategy of the City of Chełm for the years 2009-2015 and the Development Strategy of the City of Chełm. The update for the years 2015-2020 with perspective until 2030 indicates that PWSZ in Chełm constitutes a substantial workplace for the city inhabitants, and the city authorities ought to undertake efforts towards animating researchdevelopment works and creating innovations in cooperation with the scientific environment, with special consideration of the higher school in Chełm (Development Strategy for the City of Chełm for the years 2009-2015, 2009).

On the other hand, the Development Strategy for the City of Zamość until 2020 does not refer at all to the state higher vocational school which functions in the city (Development Strategy for the City of Zamość until 2020, 2014).

Taking into consideration the scope of content directly referring to state higher vocational schools one must indicate the diagnostic and programme parts of the strategy. The initial one of them contains a diagnosis of social-economic issues, characteristics of conditions and the state of development of a given territorial area as well as indicates potentials and barriers in development processes. Whilst the programme part ought to contain he most significant siłków władz uczelni zmierzających do utworzenia lotniska szkoleniowego w miejscowości Depułtycze Królewskie, a także rozwój współpracy transgranicznej uczelni, uznano za istotny element rozwoju powiatu, tym samym akcentując część diagnostyczną i programową strategii odnośnie publicznej uczelni zawodowej. Jednakże w kolejnej wersji strategii (po aktualizacji) z perspektywą do roku 2020 zabrakło zapisów w tym zakresie (Strategia Rozwoju Powiatu Chełmskiego na lata 2008-2015, 2008).

Strategia Rozwoju Powiatu Zamojskiego na lata 2007-2020 obejmuje swoim zakresem jedynie aspekt diagnostyczny dotyczący szkolnictwa wyższego, wyróżniając poszczególne szkoły wyższe funkcjonujące na terenie powiatu, w tym PWSZ im. Szymona Szymonowica w Zamościu. Natomiast brakuje tutaj aspektu programowego strategii odnośnie szkolnictwa wyższego (Strategia Rozwoju Powiatu Zamojskiego na lata 2007-2020, 2007).

W Zintegrowanej Strategii Rozwoju Miejskiego Obszaru Funkcjonalnego Biała Podlaska na lata 2015-2020 (z perspektywą do 2030 roku) zapisano, iż obszar dysponuje nowoczesnym zapleczem naukowo-badawczym, które funkcjonuje przy PSW w Białej Podlaskiej. Zaplecze to, w postaci Centrum Badań nad Innowacjami oraz Regionalnego Centrum Badań Środowiska, Rolnictwa i Technologii Innowacyjnych EKO-AGRO-TECH, stwarza możliwość współpracy z sektorem medycznym, energetycznym, drogowym, kolejowym, lotniczym, budowlanym, turystycznym, przetwórstwa spożywczego i branżą hodowlaną, a tym samym wpływa na rozwój Miejskiego Obszaru Funkcjonalnego (Zintegrowana Strategia Rozwoju Miejskiego Obszaru Funkcjonalnego Biała Podlaska na lata 2015-2020, 2015).

W Strategii Rozwoju Miasta Chełm na lata 20092015 oraz Strategii Rozwoju Miasta Chełm. Aktualizacja na lata 2015-2020 z perspektywą do roku 2030 zapisano, iż PWSZ w Chełmie to znaczące miejsce pracy dla mieszkańców miasta, a władze miasta powinny podjąć starania na rzecz animowania prac badawczo-rozwojowych i tworzenia innowacji we współpracy pomiędzy przedsiębiorstwami a środowiskiem naukowym, ze szczególnym uwzględnieniem chełmskiej uczelni (Strategia Rozwoju Miasta Chełm na lata 2009-2015, 2009).

Natomiast w Strategii Rozwoju Miasta Zamość do roku 2020 nie znalazł się żaden zapis odnoszący się do publicznej uczelni zawodowej funkcjonującej w tym mieście (Strategia Rozwoju Miasta Zamość do roku 2020, 2014).

Biorąc pod uwagę zakres ujęcia treści bezpośrednio odnoszących się do państwowych wyższych szkół zawodowych, należy wskazać część diagnostyczną i programową strategii. Ta pierwsza zawiera diagnozę problemów społeczno-ekonomicznych, charakterystykę uwarunkowań i stanu rozwoju danego obszaru terytorialnego, a także wskazywać na potencjały i bariery procesów rozwojowych. Natomiast część programowa powinna zawierać najważniejsze założenia polityki społeczno-gospodarczej, które są często ujęte w formie misji, celów strategicznych, celów szczegółowych oraz kierunków działań. 
Table 2. Scope of approach in development strategies of the Lublin region, referring to the state higher vocational schools Tabela 2. Zakres ujęcia w strategiach rozwojowych regionu lubelskiego odnoszących się do państwowych wyższych szkół zawodowych

\begin{tabular}{|c|c|c|}
\hline Type of document/ Tytuł dokumentu & $\begin{array}{l}\text { Diagnostic } \\
\text { part/ } \\
\text { Częśćc } \\
\text { diagnostyczna }\end{array}$ & $\begin{array}{l}\text { Programme } \\
\text { part/ } \\
\text { Część } \\
\text { programowa }\end{array}$ \\
\hline $\begin{array}{l}\text { Development Strategy for the Lublin Voivodeship for the years } 2006 \text { - } 2013 \text { (version from } \\
\text { 2005)/ } \\
\text { Strategia Rozwoju Województwa Lubelskiego na lata } 2006 \text { - } 2013 \text { (wersja z } 2005 \text { r.) }\end{array}$ & + & \\
\hline $\begin{array}{l}\text { Development Strategy for the Lublin Voivodeship for the years } 2014 \text { - } 2020 \text { (version from } \\
\text { 2014)/ } \\
\text { Strategia Rozwoju Województwa Lubelskiego na lata } 2014 \text { - } 2020 \text { (wersja z } 2014 \text { r.) }\end{array}$ & + & \\
\hline \multicolumn{3}{|l|}{$\begin{array}{l}\text { Regional Innovation Strategy for the Lublin Voivodeship until } 2020 \text { (version from 2014)/ } \\
\text { Regionalna Strategia Innowacji Województwa Lubelskiego do } 2020 \text { r. (wersja z 2014 r.) }\end{array}$} \\
\hline $\begin{array}{l}\text { Development Strategy for the Bialski Poviat for the years } 2007-2015 \text { (version from 2008)/ } \\
\text { Strategia Rozwoju Powiatu Bialskiego na lata } 2007 \text { - } 2015 \text { (wersja z } 2008 \text { r.) }\end{array}$ & + & \\
\hline $\begin{array}{l}\text { Development Strategy for the Chełmski Poviat for the years 2008- } 2015 \text { (version from } \\
\text { 2008)/ } \\
\text { Strategia Rozwoju Powiatu Chełmskiego na lata } 2008 \text { - } 2015 \text { (wersja z } 2008 \text { r.) }\end{array}$ & +++ & +++ \\
\hline $\begin{array}{l}\text { Development Strategy for the Zamojski Poviat for the years 2007- } 2020 \text { (version from } \\
\text { 2007)/ } \\
\text { Strategia Rozwoju Powiatu Zamojskiego na lata } 2007 \text { - } 2020 \text { (wersja z } 2007 \text { r.) }\end{array}$ & + & \\
\hline $\begin{array}{l}\text { Development Strategy for the City of Biała Podlaska for the years 2008- } 2015 \text { (version } \\
\text { from 2008)/ } \\
\text { Strategia Rozwoju Miasta Biała Podlaska na lata } 2008 \text { - } 2015 \text { (wersja z 2008 r.) }\end{array}$ & + & + \\
\hline $\begin{array}{l}\text { Integrated Development Strategy of Municipal Functional Area in Biała Podlaska for the } \\
\text { years } 2015 \text { - } 2020 \text { (version from 2015)/ } \\
\text { Zintegrowana Strategia Rozwoju Miejskiego Obszaru Funkcjonalnego Biała Podlaska na } \\
\text { lata } 2015 \text { - } 2020 \text { (wersja z } 2015 \text { r.) }\end{array}$ & +++ & \\
\hline $\begin{array}{l}\text { Development Strategy for the City of Chełm for the years } 2009 \text { - } 2015 \text { (version from } \\
\text { 2009)/ } \\
\text { Strategia Rozwoju Miasta Chełm na lata } 2009 \text { - } 2015 \text { (wersja z } 2009 \text { r.) }\end{array}$ & +++ & \\
\hline $\begin{array}{l}\text { Development Strategy for the City of Chełm. Update for the years } 2015 \text { - } 2020 \text { (version } \\
\text { from 2015)/ } \\
\text { Strategia Rozwoju Miasta Chełm. Aktualizacja na lata } 2015 \text { - } 2020 \text { (wersja z } 2015 \text { r.) }\end{array}$ & +++ & ++ \\
\hline $\begin{array}{l}\text { Development Strategy for the City of Zamość for the years } 2008 \text { - } 2015 \text { (version from } \\
\text { 2007)/ } \\
\text { Strategia Rozwoju Miasta Zamość na lata } 2008 \text { - } 2015 \text { (wersja z } 2007 \text { r.) }\end{array}$ & + & \\
\hline $\begin{array}{l}\text { Development Strategy for the City of Zamość until } 2020 \text { (version from 2007)/ } \\
\text { Strategia Rozwoju Miasta Zamość do roku } 2020 \text { (wersja z } 2007 \text { r.) }\end{array}$ & + & \\
\hline
\end{tabular}

*Symbols applied in the table indicate the approach to the discussed content in large scope (+++), in medium scope (++), in small scope (+), empty fields indicate lack of approach of the discussed content./

*Użyte w tabeli symbole oznaczają ujęcie omawianych treści w dużym zakresie (+++), w średnim zakresie (++), w małym zakresie (+), puste pole oznacza brak ujęcia omawianych treści.

Source: Own elaboration based on development strategies as well as A. Zimny, Publiczne uczelnie zawodowe w procesie rozwoju społeczno-gospodarczego w Polsce, CeDeWu, Warszawa 2017.

Źródło: Opracowanie własne na podstawie strategii rozwojowych, a także A. Zimny, Publiczne uczelnie zawodowe w procesie rozwoju społeczno-gospodarczego w Polsce, CeDeWu, Warszawa 2017.

assumptions of the social-economic policy which are frequently covered in the form of a mission, strategic targets, detailed purposes and directions of actions.

Synthetic manner of presenting the issue of problems in the tabular form indicates that the scope of approach in local strategies is significantly larger than within the regional ones. References to state higher vocational schools occur more frequently in diagnostic parts of these strategic documents. Good practice in this regard on account of large scope of approach as well as a wide involvement in the programme part is indicated by the Chełm poviat and the city of Chełm. This noticeable difference indicates
Syntetyczny sposób przedstawienia problematyki w formie tabelarycznej pokazuje, iż zakres ujęcia $w$ strategiach lokalnych jest znacznie większy aniżeli w strategiach regionalnych. Odniesienia do publicznych uczelni zawodowych częściej pojawiają się w członach diagnostycznych tych dokumentów strategicznych. Dobrą praktykę w tym aspekcie, ze względu na duży zakres ujęcia, a także szeroki udział w części programowej wykazuje powiat chełmski i miasto Chełm. Ta zauważalna różnica oznacza, że jednostki samorządu tery torialnego subregionu chełmskiego w znacznie większym stopniu uwzględniają, a co za tym idzie doceniają funkcjonowanie i działal- 
that units of territorial self-government of the Chełm subregion consider to a far more significant degree and thus appreciate the functioning and activities of state higher vocational schools than it is the case in the Bialski or Zamojski subregions.

\section{Conclusions}

The research revealed that within the strategic documents for the Lublin Voivodeship as well as its poviats and cities, statements regarding higher education refer rather to general matters than to specific higher schools. Within the local strategic documents, thus those concerning poviats and, in particular, cities it is more frequent to encounter more direct and literal references to methods of cooperation possibilities and TSU co-actions and business with state higher vocational schools for the benefit of territorial local setups, however it is an accept articulated in a more insufficient manner. Thus, establishing close cooperation between PWSZ and TSU in the scope of designing local and regional development by the authorities is the direction towards which both parties ought to turn, since one may notice substantial negligence in this scope. A perfect form of such type of cooperation are cluster structures which might include PWSZ, TSU as well as representatives of business. Such active role of the school in planning and then realizing pro-development initiatives would constitute an exemplary implementation of the social idea of higher school responsibility. To sum up one ought to note that greater and fuller cooperation of state higher vocational school with organs of local and regional authorities ought to concern both participation of scientific-research institutions at the stage of elaborating development strategies through which they would be considered within these documents and also inclusion of TSU into the process of planning school development. ność publicznej uczelni zawodowej niż ma to miejsce w przypadku subregionu bialskiego czy zamojskiego.

\section{Podsumowanie}

Badania pokazały, że w dokumentach strategicznych województwa lubelskiego, a także powiatów i miast sformułowania dotyczące szkolnictwa wyższego odnoszą się raczej do spraw ogólnych aniżeli do konkretnej szkoły wyższej. W lokalnych dokumentach strategicznych, a więc dotyczących powiatów, a szczególnie miast, częściej można zauważyć bardziej bezpośrednie i literalne odniesienia dotyczace sposobów możliwości współpracy i współdziałania JST i biznesu z publicznymi uczelniami zawodowymi dla dobra terytorialnych układów lokalnych, jednak jest to akcent wyartykułowany w sposób jeszcze niedostateczny. A zatem nawiązanie ściślejszej współpracy na linii PWSZ - JST w zakresie projektowania rozwoju lokalnego i regionalnego przez organy władzy jest tym kierunkiem, w którym powinny podążać obie strony, bowiem widoczne są zaniedbania $\mathrm{w}$ tym zakresie. Doskonałą formą do tego rodzaju współdziałania są struktury klastrowe, w których mogłyby się znaleźć PWSZ, jednostki samorządu terytorialnego, a także przedstawiciele biznesu. Taka aktywna rola uczelni $\mathrm{w}$ planowaniu, a potem realizowaniu inicjatyw prorozwojowych, stanowiłaby wzorcowy przykład implementacji idei społecznej odpowiedzialności szkoły wyższej. Reasumując należy stwierdzić, że większa i pełniejsza współpraca publicznej uczelni zawodowej z organami władzy lokalnej i regionalnej powinna dotyczyć zarówno udziału instytucji naukowo - badawczych na etapie opracowywania strategii rozwojowych, przez co byłyby one uwzględnione w tych dokumentach, ale również włączenia JST do procesu planowania rozwoju uczelni.

\section{References/ Literatura:}

1. Adamowicz, M. (2014). Przemiany w systemie edukacji szkolnictwa wyższego w Polsce. W: M. Adamowicz (red.), Państwowe wyższe szkoły zawodowe w Polsce. Dokonania, Stan obecny, Perspektywy (s. 17-32). Biała Podlaska: Wydawnictwo PSW JPII.

2. Adamowicz, M. (2003). Skala lokalna w terytorialnym podziale kraju. W: M. Adamowicz (red.), Strategie rozwoju lokalnego. Tom 1. Aspekty instytucjonalne (s. 11-23). Warszawa: Wydawnictwo SGGW.

3. Borys, T. (2010). Zrównoważony rozwój jako wyzwanie edukacyjne. W: T. Borys (red.), Edukacja dla zrównoważonego rozwoju tom I, Edukacja dla ładu zintegrowanego (s. 25-40). Białystok - Wrocław: Wydawnictwo Ekonomia i Środowisko.

4. Guzal-Dec, D. (2015). Strategie rozwoju lokalnego jako narzędzie zarządzania rozwojem gmin położonych na obszarach przyrodniczo cennych województwa lubelskiego. Roczniki Naukowe SERiA, XVII(3), 125-130.

5. Jaroszyński, M. (1971). Prawo pracowników naukowych. Wrocław: Zakład Narodowy im. Ossolińskich.

6. Klasik, A. (1996). Lokalny rozwój gospodarczy i metody jego budowania. Gospodarka lokalna w teorii i praktyce, Prace Naukowe AE we Wrocławiu, 734, 23-30.

7. Kowalska, E. (2013), Zmiana w szkolnictwie wyższym. Studium przypadków. Kraków: Oficyna Wydawnicza Impuls.

8. Regionalna Strategia Innowacji Województwa Lubelskiego do roku 2020, Lublin 2014.

9. Strategia Rozwoju Miasta Biała Podlaska na lata 2008-2015, Biała Podlaska 2008

10. Strategia Rozwoju Miasta Chełm. Aktualizacja na lata 2015-2020 z perspektywa do roku 2030, Chełm 2015.

11. Strategia Rozwoju Miasta Chełm na lata 2009-2015, Chełm 2009.

12. Strategia Rozwoju Miasta Zamość do roku 2020, Zamość 2014.

13. Strategia Rozwoju Powiatu Bialskiego na lata 2007-2015, Biała Podlaska 2008.

14. Strategia Rozwoju Powiatu Chełmskiego na lata 2008-2015, Chełm 2008.

15. Strategia Rozwoju Powiatu Zamojskiego na lata 2007-2020, Zamość 2007.

16. Strategia rozwoju województwa lubelskiego na lata 2006-2013 z perspektywa do 2020 roku, Lublin 2005.

17. Strategia rozwoju województwa lubelskiego na lata 2014-2020, Lublin 2014. 
18. Szewczuk, A., Kogut-Jaworska, M., Zioło, M. (2011). Rozwój lokalny i regionalny. Teoria i praktyka. Warszawa: C.H. Beck. 19. Ustawa z dnia 26 czerwca 1997 r. o wyższych szkołach zawodowych, Dz. U. z 1997 r., Nr 96, poz. 590, z późn. zm.

20. Ustawa z dnia 20 lipca 2018 r. prawo o szkolnictwie wyższym i nauce, Dz.U. z 2018, poz. 1668.

21. Wiatrak, A.P. (2016). Strategie rozwoju regionalnego i lokalnego jako narzędzie rozwoju i aktywności ludności. Roczniki Naukowe SERiA, XVII(6), 303-307.

22. Zasadzki, W. (2005). Wybrane problemy lokalnej i regionalnej polityki gospodarczej. W: J. Kaja, K. Piech (red.), Rozwój oraz polityka regionalna i lokalna w Polsce (s. 23-31). Warszawa: Wydawnictwo SGH.

23. Zimny, A. (2017). Publiczne uczelnie zawodowe w procesie rozwoju społeczno-gospodarczego w Polsce. Warszawa: CeDeWu.

24. Zintegrowana Strategia Rozwoju Miejskiego Obszaru Funkcjonalnego Biała Podlaska na lata 2015-2020 (z perspektywa do 2030 roku), Lublin-Biała Podlaska 2015. 